Вісник Національного університету “Львівська політехніка". Серія "Проблеми економіки та управління"

T. 4, № 1, 2020

УДК 658.001.76+330.341.1

JEL Clasification Code O31; O12; D70; D25

L. Lisovska $^{1}$, O. Yurynets ${ }^{2}$, B. Sheremeta ${ }^{1}$

Lviv Polytechnic National University,

${ }^{1}$ Management of Organizations Department,

${ }^{2}$ Department of Foreign Trade and Customs

\title{
CHANGING THE PARADIGM OF THE INNOVATION PROCESS ON THE BASIS OF INTERACTION
}

https://doi.org/10.23939/semi2020.01.174

(C) Lisovska L., Yurynets O, Sheremeta B., 2020

The article substantiates the expediency of revising and changing the paradigm of the innovation process based on the priority of the component interaction. The need for such a revision is driven by the acceleration of globalization processes, the change in the concept of partnership in innovation, the transformation of the principles of meeting consumer demands and the creation of new consumer value.

The authors examined the concepts of the innovation process and innovative activity in the legislative acts of Ukraine and research of domestic and foreign scientists and found significant contradictions between them and inconsistency with modern realities. Based on the analysis and the performed research, the authors proposed their own narrow and extended interpretation of the innovation process based on the priority of the component interaction.

Innovative processes can be carried out in different models - flowcharts and sequences of stages, different sources of new ideas and relationships between stages, which in modern theory of innovation are seven: linear (technological impetus), linear (market pull), linear with feedback interaction, integrated, network; model of open innovation; model of advanced innovation networks. The authors investigated the evolution of these models, highlighted the key characteristics of their implementation, advantages and disadvantages of implementation.

Particular attention was paid to the study of models by interaction parameters, that is, the subject of interaction, forms of interaction, interaction participants. The authors conclude that approaches to understanding and requirements for the innovation process change depending on the dynamics of market factors, economic environment of the subjects of innovation: the tasks, goals, circle of participants change. The interaction between the participants is becoming more complex, systematic, taking on different forms and methods of implementation. As the models change, the priority of the stages and their accents change. Innovation can be initiated either by the market, or by a technological stimulus, or a combination of them. The source of new ideas is an important factor, but, as the evolution of models shows, the factor that fosters interaction between the innovation process and future consumers of innovation is more important. The wider the range of potential participants in the interaction, the greater the likelihood of commercial success in innovation.

Thus, the effectiveness of the innovation process is determined by the indicators of establishing interaction between stages and participants of innovation, mainly information efficiency of the process, indicators of establishing communications through the innovation network.

Key words: innovation activity, interaction, innovative cooperation, innovation process, models of management of innovation process, stages. 


\section{Introduction}

The large number of participants, the cost and quality requirements for the composition and structure of the resource, high risk and unpredictability of results, potentially high returns are the characteristics that traditionally associate with the innovation process and which determine its economic specificity in the market.

The acceleration of the processes of renewal in the market of technologies and intellectual products, the globalization of the world economy, the transition of the development of national systems to the principles of openness and socialization make it necessary to review the filling of the concept of "innovation process".

In classical interpretations, the innovation process is understood as a set of stages for the transformation of new knowledge into an innovation, combining the stages of "science" and "commercialization of innovations". This understanding does not allow a comprehensive and systematic approach to the formation of modern mechanisms for improving the efficiency of innovation activity of the subjects of the innovation environment. Many systemic factors and principles of innovation activity in the modern world remain unaddressed: the transition from rivalry models to consumer preference and access to the necessary resources to the cooperation model in creating new consumer value, development of the concept of triple spiral interaction "University - Business - Business" Open Innovation, Community Concepts 5.0 and more. Not only are the basic principles of scientific activity changing, but also the principles of diffusion and diffusion of innovations, and national innovation systems become an element of a higher level system - the International Innovation System [1, p. 64].

\section{Analysis of recent researches and publications, problem statement}

There is no legally defined concept of "innovation process". In the Order of the State Statistics Committee of Ukraine the innovative process refers to the introduction of a new or significantly improved production process, method of distribution or activity in support of goods and services [2]. Such an interpretation can be considered analogous to the understanding of technology, that is, "a set of systematic scientific knowledge, technical, organizational and other decisions on the list, timing, procedure and sequence of operations, the process of production and / or sale and storage of products, services" [3].

Instead, it is possible to analyze the interpretation of the concept of "innovation activity" in the legislative acts. In the legislation of Ukraine the concept of innovative activity is defined as "activity", "set of measures" and "actions". According to the Law of Ukraine "On Innovative Activity" the term "Innovative Activity is an activity aimed at using and commercializing the results of research and development and causing the launch of new competitive goods and services" [4].

According to the Law of Ukraine "On Investment Activity" Innovative activity is a set of measures aimed at creation, implementation, dissemination and realization of innovations in accordance with the Law of Ukraine "On Innovation Activity" with the purpose of obtaining commercial and / or social effect, which are carried out by realization of investments, invested in the objects of innovation activity [5].

In scientific research, the term innovative activity is regarded as: activity; West; action; development and implementation; state achievement; way; system; process; work; types of work [6, p. 6].

Instead, scientists have developed a large number of approaches to understanding the innovation process and innovation.

Analyzing the position of scientific works of Ukrainian scientists, it is possible to ascertain the lack of consensus in the interpretation and use of the concepts innovative activity and innovative process. Namely, regarding the internal compatibility of these concepts. Some treat innovation as an activity, others treat it as a process [7, p. 275].

M. V. Chorna, S. V. Glukhova (2012) argue that the concept of "innovation activity" is broader than the concept process, since it has a continuous and unlimited character [8, p. 19].

There are approaches that combine the two approaches. For example, Lutsykov, I. V. (2010) states that "Innovative activity in its entirety is complex, systematic in nature and includes such kinds of work as 


\section{Lisovska, O. Yurynets, B. Sheremeta}

search for ideas, licenses, patents, personnel, organization of research work, engineering and technical activity, which unites invention, rationalization, designing, creation of engineering and technical objects, information and marketing activity "[9, p. 91]. In other words, the author includes other activities and the initial stages of the innovation process.

Jejula, V. V., Epifanova, I. Y., \& Zvik, A. G. (2017) note that innovation is a complex of economic, technical, legal, social measures related to the development, implementation and use of innovation which aims to achieve certain economic and / or social effects [6, p. 8]. This understanding implies a set of activities (works) at all stages of the innovation process.

Utterback, J. M., \& Abernathy, W. J. (1975) argue that the characteristics of a firm's innovation process and innovation endeavors will vary systematically depending on the firm's environment, competition strategy and growth strategy, as well as the state of the technology used by the firm and its competitors. Therefore, in their opinion, it is necessary to speak about dynamic models of managing the innovation process. This study also identifies three types of innovation process management models, depending on the type of innovation: products, technology, or technical systems. These models are based on differences in the processes of development and deployment of their production resources and sources of new ideas for starting an innovation process [10, p. 642].

Bigliardi, B., Colacino, P., \& Dormio, A. I. (2011) noted that one of the main obstacles facing companies in developing and implementing innovations is the difficulty of partnering with other companies, financial problems and lack of resources in companies. Scientists say that the innovation process is initiated by the ideas of consumers and suppliers. It is correct to consider, according to the authors, that, especially at the first stage of the innovation process, interaction between the production company and the end consumer of its production becomes very important [11, p. 88].

Hsiao, S. W., \& Chou, J. R. (2004) in their work emphasize the need to include models and methods of managing creativity of both individuals and teams of innovators in the stages of the innovation process $[12$, p. 430].

The importance of collective learning processes in the development and use of new technologies is noted by O'Sullivan, M. (2000). They believe that technologies are developed and used by integrating groups of people into processes of collective learning [13, p. 395].

Von Hippel, E. (1976) has conducted a quantitative study of industrial successful innovations and states that the process over the past few years has demonstrated conclusively:

(1) Approximately three out of four successfully developed industrial innovation projects are initiated in response to a user's perceived need for innovation, not based on the technological capability of achieving them.

(2) An accurate understanding of the consumer's needs is the factor that most strongly distinguishes between commercially successful innovative projects and those that fail [14, p. 214].

Verworn, B., \& Herstatt, C. (2002) gave a brief overview of the emergence and advancement of process models in two regions. We tried to select models that had a significant effect on innovation research or practice. With regard to the vast number of process models described in the literature, our selection is highly subjective.

In North America, Cooper's stage-gate-process has given direction to the spread of process models in practice. Cooper also stimulates the emergence of standardized processes in the German-speaking area. However, particularity in this area is the utilization of requirement specifications and functional specifications [15].

\section{Purpose and tasks of the research}

This study seeks to substantiate the concept and content of the innovation process in relation to determining the priorities for the development of modern innovation environment.

To achieve this goal, the authors analyzed the peculiarities of the innovation process management models and identified the key factors for their differentiation and evolution. 


\section{The main material}

The innovation process involves three stages, each of which involves a number of stages. In scientific and technical activities, the stage (phase) is understood as a set of works, characterized by the features of their independent planning and financing, aimed at obtaining the intended results and is subject to separate acceptance. Each separate stage can be an independent result of intellectual activity, the fact of which implementation does not depend on the moment of completion of works as a whole (Fig. 1).

The set of works on the implementation of the stages of basic research, search and applied research is called the stage "Science".

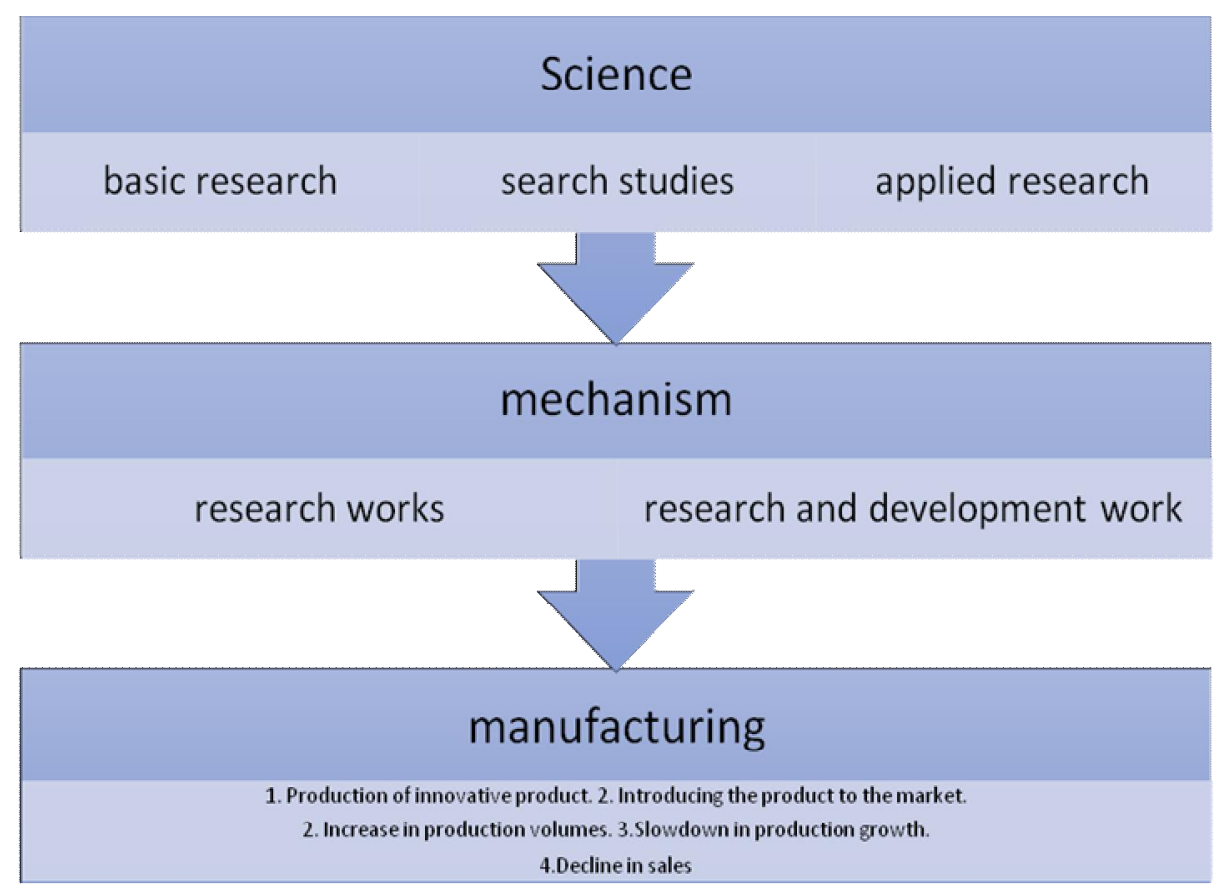

Fig. 1. Structure of the innovation process [16, p. 34]

At the "Mechanism" stage of the innovation process, they perform technical activities in the form of scientific and technical (experimental) developments.

The list of scientific and technical developments includes design and technological works, works on creation of prototypes (batches) of products (products), as well as design works for construction [17].

The third stage of the manufacturing innovation process includes experimental verification of the recommendations research and development works (RDW) and technological works (TW), their alignment with the needs of specific organizations and enterprises.

This component includes the stages of researching-experimental works (REW), the stages of marketing support, the introduction of a new product, the development of a marketing program and the promotion of new products on the market.

REW completes the stage of development of industrial production of new products and begins the process of industrial production (IP) or introduction into economic activity. Knowledge materializes in production (business), and research reaches its logical conclusion.

In addition to the technical and technological support for the innovation process underway at this stage, it is important to accompany all stages with marketing support.

The stage of commercialization of innovation can be the final stage in the innovation process. In modern research, the innovation process involves the spread of innovation [18, p. 21].

Dissemination can occur through an information process, the form and speed of which depends on communication channels, the ability of business entities to perceive and use this information. 


\section{Lisovska, O. Yurynets, B. Sheremeta}

The dissemination of innovation can take the form of diffusion, a process of diffusion of innovation into other fields, industries, resulting in innovations penetrating into different uses and finding more and more consumers. Lacom, P., Bazzaro, F., \& Sagot, JC (2017) note that the innovation process is divided into four domains (marketing and sales; technology; legal, normative and financial; management and organization), and in four steps (exploration; assessment and decision; project management; capitalization). The interaction between these domains and steps enables one to determine the actions of the process. For each of these actions, it is possible to define the methodological, human, material, and technological resources that are required to achieve them [19, p. 28].

In order to study the current trends of changes and characteristics of the innovation process, it is advisable to turn to models of innovation management.

Innovative processes can be carried out according to different models - flow charts and sequences of stages implementation, different sources of new ideas and interrelations between stages, which in modern theory of innovation are seven [18, 20,21]:

$>$ linear (technological impulse),

$>$ linear (market pull),

$>$ linear with the feedback of the interaction,

$>$ integrated

$>$ network

$>$ model of open innovation;

$>$ model of expanded innovative networks.

These models are conceptually different in nature and in order to establish relationships with market participants.

The first generation of innovative process models include classic "linear" processes that are "pushed by technology (the lab)" (technology push).

They were implemented from the mid-1950s to the end of the 1960s. The innovation process began in scientific technological laboratories, where discoveries were made, and during the stages of the innovation process, new knowledge was transformed into new products. Thus, the success of innovation was ensured by concentrating resources on the first stages of the innovation process, namely R\&D. Therefore, the main focus was on scientific research and development of science and technology. The process of transforming $\mathrm{R} \& \mathrm{D}$ results into new products, services, or processes, according to neoclassics, was inevitable. Critics of this model have noted that there is a large gap between the parameters of the new product and the parameters of the consumer need that has not been studied.

The second generation of innovation process models spread in the mid-1960s - early 1970s. Such demand-driven models, ie, innovations, must be developed and the innovation process must be driven by unmet market needs. However, eliminating the shortcomings of the previous model, appeared their own. The new problems have been compounded by the difficulty of converting consumer requirements into a real materialized entity and assessing the technical capabilities of the entities involved in the innovation process for such implementation.

The Linear Interaction Feedback or Interactive model has emerged in response to global changes in increasing competition and shortening product life cycles. In it, the innovation process is seen as a combination of the two previous models. The interactive model was linear, but the role of combining new knowledge with the old was emphasized. Proponents of this model argued that when looking for new technological solutions, entities must first turn to existing knowledge. Only when the existing level of knowledge fails to satisfy their technological demands (requirements), does the creation of new knowledge (with the help of R\&D) begin.

Unlike previous models, engagement was seen as a success factor for innovation. The model included an element of two types of interactions: internal - between organizational units and external with other market entities. These models emphasized the need to strengthen links between the various units of the organization. The importance of the interaction between the stages of scientific and technical 
development and marketing was emphasized. It was believed that new ideas could emerge in any unit, and therefore interaction between the different units was an integral part of the innovation process.

Within the third generation, processes are selected the Stage-Gate model from Cooper [22, c. 545]. This model divides the product innovation process into stages with defined gates acting as decision points between the stages (Fig. 2).

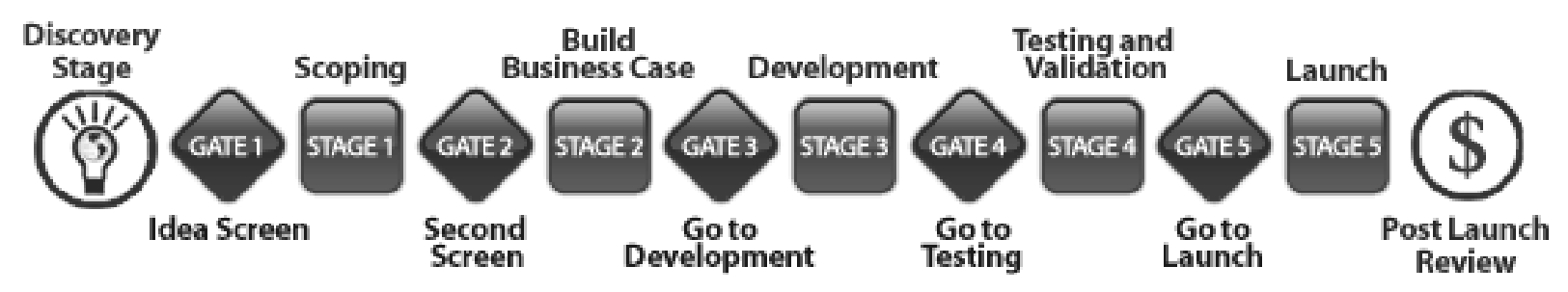

Fig. 2. Stage Gate Process [22]

In the mid-1980s, a new generation of innovative process models emerged - integrated. The model envisaged the integration of research and development with production, and interaction with suppliers and buyers, that is, internal interaction in the organization should ensure the reduction of the scientific and technological development while reducing the cost of innovation. At the same time, the importance of such a form of external interaction as horizontal cooperation (creation of joint ventures, strategic alliances) has significantly increased.

In the 1990s, the "network" model was based on the notion that it was necessary not only to unite the various units of the enterprise around the innovation process, but also to create and strengthen their network connections with consumers, suppliers and other institutions. This formed the so-called "system of innovations" [23, p. 66]. In this decade, the so-called "systems of innovative theories" appeared. The concept of "innovation ecosystem" should be included in the network model of the innovation process. This model provides for forms of collaboration in which organizations combine their individual offerings into integrated solutions ready for use by the consumer in the market. Particular emphasis in these models is placed on hidden knowledge and, consequently, on mechanisms that will allow them to increase.

The basic idea behind network models was that interaction and knowledge sharing should take place not only between different units of the enterprise, but also with other "sources of knowledge" (enterprises, universities, research centers, consumers, suppliers). In these models, special attention is paid to the process of knowledge accumulation and use of external links, creation of systems of integration.

In particular, the network model, which began to develop since the mid-1990s, is characterized by high system integration; flexible organizational structure; Effective external communication channels focusing on strategic relationships between individual organizations involved in the process.

The innovation process remains a network-integrated process, but more attention is paid to mechanisms that allow for the creation, dissemination and use of all types of knowledge.

In the late 1990s, interest in rapid learning emerged and began to grow as a major source of knowledge and, therefore, a major source of competitive advantage for the enterprise. The faster an enterprise is able to learn, the more innovative it is, the faster it is able to respond to market changes with innovative products and services. Thus, everything related to strategic learning is part of what can be called the sixth model of the innovation process.

The occurrence of the sixth generation of Open Innovation Innovation Process models in the early 2000s is associated with the name Henry Chesbrough. The model assumes that the organization as a subject of the innovation process can and should use both its own and others' ideas. Instead, the organization should provide access to other entities for the use of its intellectual property. Such mutual exchange, while creating problems in the intellectual property market, should facilitate the emergence of excess knowledge and the rapid flow of the innovation process. 


\section{Lisovska, O. Yurynets, B. Sheremeta}

The Open Innovation Model is based on six basic principles:

1) the principle of interaction - cooperation with employees outside the company will reduce the loss of unused ideas;

2) principle of involvement - external innovative ideas should be considered at the level with the company's internal R\&D;

3) the principle of cooperation - companies do not have to carry out independent research in order to profit from the results;

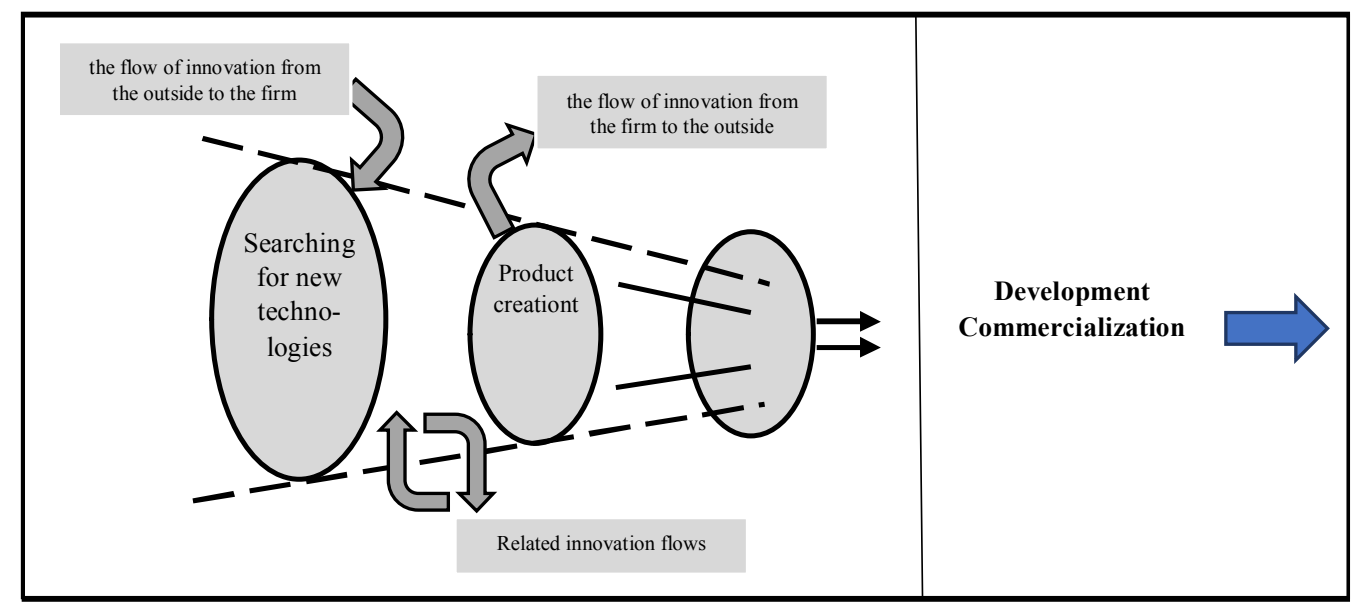

Fig. 3. Stages of innovation process according to the concept of "open innovation" [21]

4) the principle of modeling - the company must build a perfect business model before entering the market;

5) the principle of optimization - the company will be the leader if the best way to optimize the use of internal and external ideas;

6) profitability principle - the company must activate its activities in the intellectual property market in order to profit from the existing intellectual property [24].

The open innovation model is built on the intensive use of horizontal interactions with suppliers, consumers, etc., and vertical interactions through the creation of joint ventures, consortia and more.

Rylach, N.M (2018) argue that vertical alliances complement horizontal alliances and cross-industry partnerships, which aim to save, reduce transaction costs and create goods [25].

The disadvantages of implementing this model include: additional costs of managing cooperation with external partners, lack of control, negative impact on flexibility, (excessive) dependence on external parties and potentially opportunistic behavior of partners [25].

The seventh model of the innovation process, Advanced Innovation Networks, integrates the principles of open innovation innovation and networking. The main priority of the model is the person as the carrier of the innovative idea.

Within this model, the creation of a joint innovation proposition occurs through virtual networks, without the formation of such "burdensome" structures as strategic alliances. It is not the search for ideas, but the communities, for the implementation of particular innovation processes. The implementation of the innovation process involves the application of the principles of convergence, spillover efficiency and diffusion of innovation into different spheres of public life.

This model involves the construction of an integrated knowledge transfer network. Instead of the traditional stages of the innovation process of linear models, network communities and individuals emerge to share ideas and knowledge in the network economy.

Du Preez, N. D., \& Louw, L. (2008, July) summarize that the innovation environment has changed through networking and collaboration from simple linear models to the more complex integrated network 
models. Open innovations call for a new logic, prescribing openness and collaboration at its center. Networked or webbed communities are the open and agile vehicles to pragmatically deploy open innovation concepts. In the new networked paradigm it is possible to exploit linear and coupling processes in combination depending on the requirements [22].

Separation of characteristic features of seven generations of models of innovation process allows to assert that there is a fundamental transformation of understanding and value of interaction.

The course of interaction is accompanied by a change in the state of the stages of the innovation process in space and time, through the constant coordination of conditions and forms of cooperation and the share of each participant in the resource provision of activities and expected economic results from implementation during the innovation life cycle [26, p. 91].

Figure 5 shows the components of the innovation process that underwent the greatest rethinking and rebooting over the evolution of the models.

Table presents the elements of the system of interaction (types of knotches, subject of ties, participants, tasks of ties) in accordance with generations of models of the innovation process.

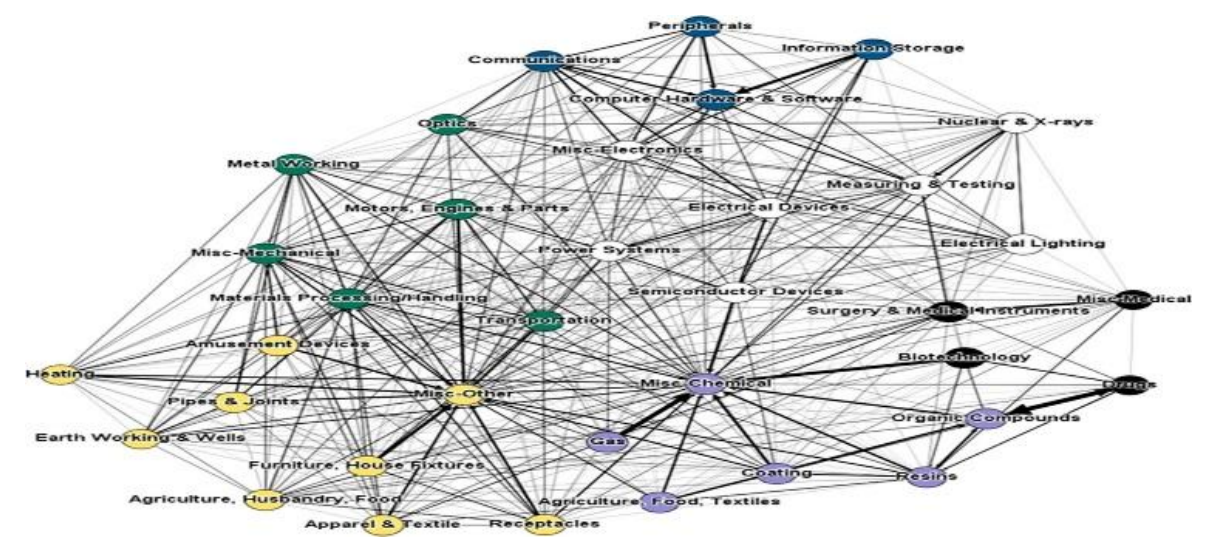

Fig. 4. Model of innovation process of extended innovation networks [22]

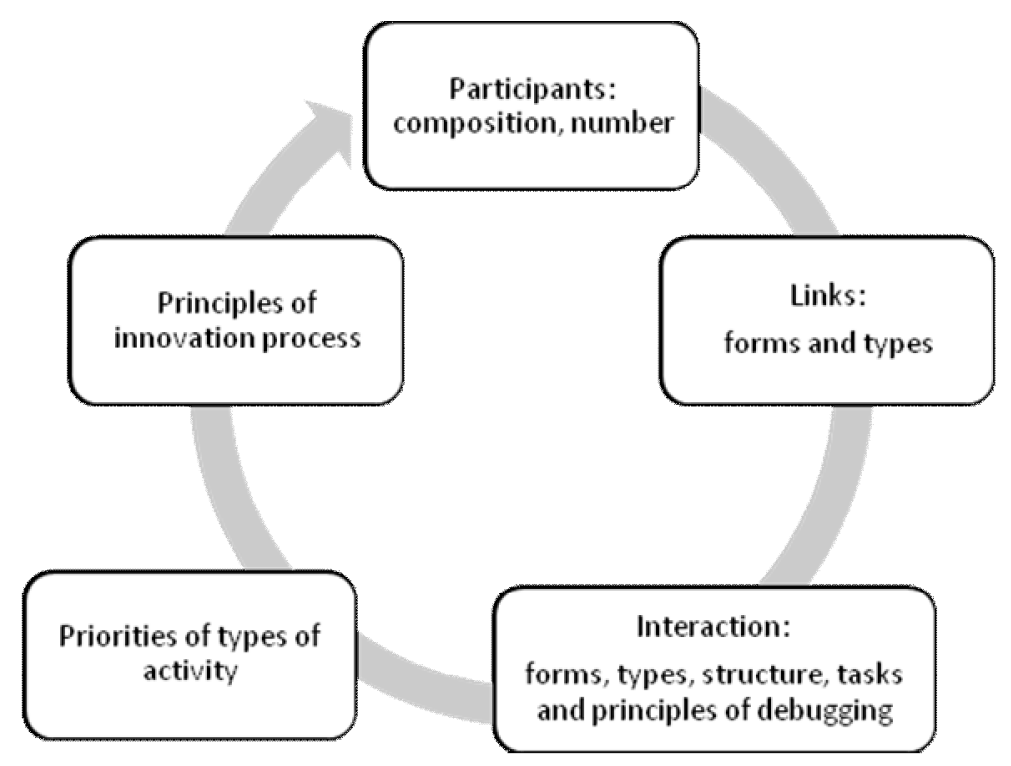

Fig. 5. Elements of the implementation of the innovation process, which changed the meaningful content during the evolution of models of the innovation process *

* Authors' own development. 


\section{Lisovska, O. Yurynets, B. Sheremeta}

The evolution of innovation process models involves an increase in the number of participants. If in linear models the innovation processes involved the involvement of only employees of the innovation organization, then in the extended innovation models, there are even communities from related economic activities. A prerequisite is the interest and participation of the subjects in the creation of new innovative value.

Forms and types of connections between participants are transformed. In linear models, connections were established between the performers of the process steps, they were linear. Network models use "flow of ideas" as a form of debugging. "Hard" forms of joint activity in the form of hierarchical structures are not required.

\section{Characterization of the evolution of the innovation process model by type of communication*}

\begin{tabular}{|c|c|c|c|}
\hline Model Type & Types of connections & Subject matter, Members & Tasks of connections \\
\hline $\begin{array}{c}\text { Linear ("technological } \\
\text { push") }\end{array}$ & $\begin{array}{c}\text { Internal lines of } \\
\text { communication between } \\
\text { groups of executors of an } \\
\text { organization (process steps) }\end{array}$ & $\begin{array}{l}\text { Expectation of the results of } \\
\text { the stage, } \\
\text { Performers work within } \\
\text { stages }\end{array}$ & $\begin{array}{c}\text { Transmission of } \\
\text { intermediate results of } \\
\text { stages }\end{array}$ \\
\hline $\begin{array}{l}\text { Linear } \\
\text { ('Market } \\
\text { extension") }\end{array}$ & $\begin{array}{l}\text { Internal lines of } \\
\text { communication between } \\
\text { groups of executors of an } \\
\text { organization (process steps) }\end{array}$ & $\begin{array}{l}\text { Establishing contacts with } \\
\text { consumers to identify the } \\
\text { need in the initial stages of } \\
\text { the process; } \\
\text { Performers work within } \\
\text { stages }\end{array}$ & $\begin{array}{c}\text { Transmission of } \\
\text { intermediate results of } \\
\text { stages }\end{array}$ \\
\hline $\begin{array}{c}\text { Linear with } \\
\text { the reverse } \\
\text { connections (interactions) }\end{array}$ & $\begin{array}{l}\text { Internal linear } \\
\text { and feedback }\end{array}$ & $\begin{array}{l}\text { Internal - between groups } \\
\text { of executors of the } \\
\text { organization (process } \\
\text { stages) and external - with } \\
\text { other market entities, are } \\
\text { periodic }\end{array}$ & $\begin{array}{l}\text { Coordination of the } \\
\text { intermediate results of the } \\
\text { stages with the } \\
\text { requirements of market } \\
\text { needs and existing } \\
\text { knowledge }\end{array}$ \\
\hline Integrated & $\begin{array}{l}\text { Internal links between the } \\
\text { organization's performing } \\
\text { groups (process steps) and } \\
\text { horizontal collaboration } \\
\text { feedbacks }\end{array}$ & $\begin{array}{l}\text { Internal - between groups } \\
\text { of executors of the } \\
\text { organization (process steps) } \\
\text { and external - with other } \\
\text { market entities, are } \\
\text { permanent } \\
\end{array}$ & $\begin{array}{l}\text { Joint implementation of } \\
\text { stages and reconciliation of } \\
\text { results with market needs }\end{array}$ \\
\hline Network & $\begin{array}{c}\text { External links on a } \\
\text { competitive basis between } \\
\text { market participants }\end{array}$ & $\begin{array}{l}\text { Finding and setting up joint } \\
\text { activities in the external } \\
\text { environment, all market } \\
\text { participants interested in the } \\
\text { process } \\
\end{array}$ & $\begin{array}{c}\text { Joint execution of works by } \\
\text { stages (creation of a single } \\
\text { proposal) }\end{array}$ \\
\hline Open innovation & $\begin{array}{l}\text { Horizontal External } \\
\text { Relations with Suppliers, } \\
\text { Consumers, etc., and } \\
\text { Vertical External Relations } \\
\text { with Organizations }\end{array}$ & $\begin{array}{l}\text { Finding and setting up joint } \\
\text { activities in the external } \\
\text { environment, all market } \\
\text { participants interested in the } \\
\text { process }\end{array}$ & $\begin{array}{l}\text { Mutual exchange of new } \\
\text { ideas and development } \\
\text { results, } \\
\text { Joint implementation of } \\
\text { stages through the creation } \\
\text { of joint ventures, consortia }\end{array}$ \\
\hline $\begin{array}{l}\text { Advanced innovation } \\
\text { networks }\end{array}$ & $\begin{array}{l}\text { All kinds of connections in } \\
\text { an online environment with } \\
\text { innovative organizations }\end{array}$ & $\begin{array}{l}\text { All participants in the } \\
\text { creation and use of } \\
\text { innovation in the target and } \\
\text { all potential markets }\end{array}$ & $\begin{array}{l}\text { Sharing all possible } \\
\text { outcomes of the innovation } \\
\text { and dissemination } \\
\text { processes, } \\
\text { Finding directions for } \\
\text { convergence of innovation } \\
\text { and spillover effect } \\
\text { forecasting }\end{array}$ \\
\hline
\end{tabular}

* Made on the basis of [14, 18, 20, 22, 23, 25]. 


\section{Changing the paradigm of the innovation process on the basis of interaction}

As generations of models of the innovation process change, marketing methods and tools are also deformed. As noted by Sobolev, TO, \& Hudyma, AG (2016), tools such as geo-targeting, internet marketing, realtime communications and more are emerging. Among the methods can be distinguished stetelling (in English - "storytelling"), ie the promotion of goods through vivid visual images and stories; canceengineering, or "emotional design" (the desire to transform emotions and human experiences into specific properties of products and their design); the concept of "six sigmas", economical production, etc. [27, p. 286].

The tasks of the innovation process are also changing. As Fingar notes, P (2012) one of the challenges is how an innovation process is structured enough to keep the innovation process flowing, yet not so rigid as to stifle. The innovation process will need to be able to accomplish the following [28]:

- Establish and mature innovation methodologies and common framework across the company

- Systematically identify high value external and internal targets for innovation

- Capture, evaluate, prioritize, and catalog innovative ideas

- Sponsor, develop, and refine those that have merit

- Promote the production of those that bring real value

- Facilitate adoption into operational environments

- Pilot and perform proof of concept projects

- Develop innovation experts to provide innovation consulting, training and Innovation Plan

- development

- Provide the processes, tools, templates, and resources that allow innovation teams to

- produce solid Innovation Plans.

Thus, approaches to understanding and requirements for the innovation process change depending on the dynamics of market factors, economic environment of the subjects of innovation.

The conducted research and the results obtained from it allow us to form such a definition and understanding of the innovation process.

Narrowing approach: "a coherent process of working together to transform knowledge into a new way of addressing consumer needs. In the broader sense, the innovation process should be understood as the set of stages of collaboration (action and interaction) of individual entities or communities to transform new or existing knowledge into innovation (new consumer needs solution or new consumer value) that combine efforts and interests with principles openness of ideas and knowledge, interpenetration of activity.

The global economic space is undergoing constant changes: the pace of production and consumption technologies is increasing, the timing of innovation is decreasing, consumers are becoming participants in innovation, and competitors are partners in the implementation of the innovation project.

Understanding how it is necessary to build new systems of interaction in innovation processes will allow to establish mechanisms for stimulating innovation in our country.

\section{Conclusions}

Most models of the innovation process involve the execution of standard types of work during the stages, namely: idea generation and identification, concept development, concept evaluation and selection, development and implementation. However, the priority of the stages and their accents change. Innovation can be initiated either by the market, or by a technological stimulus, or a combination of them. The source of new ideas is an important factor, but as the evolution of the models shows, the factor that fosters interaction between the innovation process and future consumers of innovation is more important. The wider the range of potential participants in an interaction, the greater the likelihood of commercial success in the innovation.

Creation of multifunctional teams becomes of great importance in modern innovative models as innovations become more complicated, they become multivariate in application, more and more often the emergence of a spillover effect is established, and the interconnections between different branches (fields) of science are required. 


\section{Lisovska, O. Yurynets, B. Sheremeta}

The acceleration of the innovation process and the use of the concept of "open innovation" causes a very frequent rejection of the patenting institute, which requires time and resources to be diverted from the innovation process.

Information and knowledge play a very important role in all models of the innovation process, especially during the initial stage of identification and concept creation, when new opportunities are needed and important decisions are made. The evolution of models of the innovation process has affected the understanding of indicators of quality of information and knowledge. Priority is given to the subject of innovation - the person as the bearer of knowledge.

Thus, the effectiveness of the innovation process is determined by the indicators of establishing interaction between stages and participants of innovation, mainly information efficiency of the process, indicators of establishing communications through the innovation network.

In the following studies, it is advisable to consider the forms and ways of establishing interaction in innovation processes, to compare them and to determine the most effective among them in the current conditions of the Ukrainian innovation environment.

1. Мрихіна, О. Б. (2018). Обгрунтування концептуального підходу до трансферу технологій з університетів у бізнес-середовище на засадах теорії фракталів. Міжнародний науковий журнал Інтернаука. Серія: Економічні науки, (1), 62-71.

2. Наказ ДержкомстатуУкраїни від 01.10.2008 р. № 361 “Інструкція щодо заповнення форми державного статистичного спостереження N1-інновація", положення 4.1. Available at: http://zakon.rada.gov.ua/ cgibin/laws/main.cgi?nreg=z1047-08.

3. Закон України Про державне регулювання діяльності у сфері трансферу технологій від 14.09.2006 № 143-V. Available at:https://zakon.rada.gov.ua/laws/show/143-16/ed20110101/find? text=\%D2 \%E5 \%F5 $\%$ ED \%EE \%EB \%EE \%E3 \%B3 \%FF

4. Закон України Про інноваційну діяльність (Відомості Верховної Ради України (ВВР), 2002, № 36, ст. 266) - Ст.1 Available at: https://zakon.rada.gov.ua/laws/show/40-15

5. Закон України "Про інвестиційну діяльність" Документ 1560-XII, чинний, поточна редакція - Редакція від 20.10.2019, підстава - 155-IX - Ст.3. Available at: https://zakon.rada.gov.ua/laws/show/1560-12

6. Джеджула, В. В., Єпіфанова, І. Ю., \& Цвик, О. Г. (2017). Інноваційна діяльність як чинник конкурентоспроможності підприємств. Інвестиції: практика та досвід 4: 5-8.

7. Захаркін, О. О. (2013). Інноваційна діяльність підприємства: теоретичний аспект. Проблеми економіки, (4), 274-280.

8. Чорна, М. В., Глухова С. В. (2012) Оцінка ефективності інноваційної діяльності підприємств. Харків. держ. ун-т харчування та торгівлі,210 c.

9. Луциків, І. (2010). Економічна суть інноваційної діяльності.Галицький економічний вісник, 2010, № 2(27), C.89-95.

10. Utterback, J. M., \& Abernathy, W. J. (1975). A dynamic model of process and product innovation. 1975, 3(6), $639-656$.

11. Bigliardi, B., Colacino, P., \& Dormio, A. I. (2011). Innovative characteristics of small and medium enterprises. Journal of technology management \& innovation, 6(2), 83-93.

12. Hsiao, S. W., \& Chou, J. R. (2004). A creativity-based design process for innovative product design. International journal of industrial ergonomics, 34(5), 421-443.

13. O'Sullivan, M. (2000). The innovative enterprise and corporate governance. Cambridge Journal of Economics, 24(4), 393-416.

14. Von Hippel, E. (1976). The dominant role of users in the scientific instrument innovation process. Research policy, 5(3), 212-239.

15. Verworn, B., \& Herstatt, C. (2002). The innovation process: an introduction to process models (No. 12). Working paper.

16. Чухрай, Н. І., Лісовська, Л. С. (2015). Управління інноваціями: [навч. посіб.]. Львів: Вид-во Львів. політехніки, 277 с. 


\section{Changing the paradigm of the innovation process on the basis of interaction}

17. Методичні рекомендації щодо проведення аналізу результативності науково-технічної діяльності (для первинних організацій) // СХВАЛЕНО Рішенням Вченої ради УкрІНТЕІ Протокол від 28.12.2010 р. № 10.

18. Даниленко, Ю. А. (2018). Характеристики та класифікації інновацій та інноваційного процесу, Наука та інновації, Т.14, № 3, С.15-30. Available at: укр.// http://dspace.nbuv.gov.ua/handle/123456789/134025

19. Lacom, P., Bazzaro, F., \& Sagot, J. C. (2017). Proposal of a Modelling of the Innovation Process in an International Manufacturing Company. Journal of technology management \& innovation, 12(2), 26-33..

20. Чухрай, Н. Патора, Р. (2001). Інновації і логістика товарів: Монографія. Видавництво Національного університету “Львівська політехніка”, 264 с.

21. Гареев, Т. Ф. (2006). Эволюция моделей инновационного процесса. Вестник Тисби № 2, 2006 [Електронний ресурс]. Available at:: http://www.tisbi.ru/science/vestnik/2006/issue2/econom4.html.

22. Du Preez, N. D., \& Louw, L. (2008, July). A framework for managing the innovation process. In PICMET'08-2008 Portland International Conference on Management of Engineering \& Technology (pp. 546-558). IEEE..

23. Голубєва, Т. С.(2006). Методологічні підходи до оцінки ефективності діяльності підприємства . Актуальні проблеми економіки, № 5, С.66-71.

24. Chesbrough H. (2003) Open Innovation. The New Imperative for Creating and Profiting from Technology. Harvard Business Press, 2003. Available at:: https:/eclass.uoa.gr/modules/document/file.php/ECON197/ Papers \%20Strategy/Chesbrough \%20 2003 \%20The \%20Era \%20of \%20Open \%20Innovation.pdf (дата звернення: 12.03.2020).

25. Рилач, Н. М. (2018). Теоретичні основи та сучасні тенденції розвитку відкритих інновацій. Міжнародні відносини Серія" Економічні науки”, (12).

26. Лісовська, Л. С., Лютак, О. М., \& Здоровега, М. В. (2019). Фактори та проблеми налагодження співпраці з питань інновацій в Україні.

27. Соболєва, Т. О., \& Гудима, О. Г. (2016). Трансформація маркетингу інновацій в моделях інноваційного процесу. Бізнес Інформ, (4), 284-288.

28. Fingar, P. (2012). The Innovation Process (Adapted from the book, Business Innovation in the Cloud: Executing on Innovation with Cloud Computing). Available at: https://www.bptrends.com/publicationfiles/06-05-2012COL-EXT \%20COMPETITION--Innovation \%20Process-Fingar-Final.pdf

1. Mrykhina, O. B. (2018). Obgruntuvannia kontseptualnoho pidkhodu do transferu tekhnolohii z universytetiv u biznes-seredovyshche na zasadakh teorii fraktaliv [Substantiation of conceptual approach to technology transfer from universities to business environment based on fractal theory]. International scientific journal Internauka. Series: Economic Sciences, (1), 62-71. [in Ukrainian].

2. Nakaz Derzhkomstatu Ukrainy vid 01.10 .2008 r. N 361 "Instruktsiia shchodo zapovnennia formy derzhavnoho statystychnoho sposterezhennia N1-innovatsiia”, polozhennia 4.1.[Order of the State Statistics Committee of Ukraine of 01.10.2008 N 361 "Instruction on filling in the form of state statistical observation N1-innovation", clause 4.1] [in Ukrainian]. Retrieved from: http://zakon.rada.gov.ua/cgi-bin/laws/main.cgi?nreg=z1047-08.

3. Zakon Ukrainy Pro derzhavne rehuliuvannia diialnosti u sferi transferu tekhnolohii vid 14.09.2006 \# 143-V.[Law of Ukraine On State Regulation of Activities in the Field of Technology Transfer of 14.09.2006 No. 143-V.] [in Ukrainian]. Retrieved from:https://zakon.rada.gov.ua/laws/show/143-16/ed20110101/find?text=\%D2 \%E5 \%F5 \% $\mathrm{ED} \% \mathrm{EE} \% \mathrm{~EB} \% \mathrm{EE} \% \mathrm{E} 3 \% \mathrm{~B} 3 \% \mathrm{FF} /$

4. Zakon Ukrainy Pro innovatsiinu diialnist (Vidomosti Verkhovnoi Rady Ukrainy (VVR), 2002, \# 36, st.266) St.1 [4. Law of Ukraine On Innovative Activities (Verkhovna Rada of Ukraine (BBR), 2002, No 36, Art. 266) - Article 1] [in Ukrainian]. Retrieved from:https://zakon.rada.gov.ua/laws/show/40-15

5. Zakon Ukrainy "Pro investytsiinu diialnist" Dokument 1560-XII, chynnyi, potochna redaktsiia - Redaktsiia vid 20.10.2019, pidstava - 155-IX - St. 3. [5. Law of Ukraine "On Investment Activity” Document 1560-XII, in force, current version - Revision from 10/20/2019, ground - 155-IX - Article 3.] [in Ukrainian]. Retrieved from:https://zakon.rada.gov.ua/laws/show/1560-12

6. Dzhedzhula, V. V., Yepifanova, I. Yu., \& Tsvyk, O. H. (2017). Innovatsiina diialnist yak chynnyk konkurentospromozhnosti pidpryiemstv.[ Innovative activity as a factor of competitiveness of enterprises. Investment] Practice and Experience 4: 5-8. [in Ukrainian]. 


\section{Lisovska, O. Yurynets, B. Sheremeta}

7. Zakharkin, O. (2013). Innovatsiina diialnist pidpryiemstva: teoretychnyi aspekt [Innovative activity of the enterprise: theoretical aspect]. Problems of economy, No. 4, 2013, 274-280. [in Ukrainian]. Retrieved from: https://www.problecon.com/export_pdf/problems-of-economy-2013-4_0-pages-274_280.pdf.

8. Chorna, M. V, Hlukhova S. V. (2012). Otsinka efektyvnosti innovatsiinoi diialnosti pidpryiemstv.[ Assessment of efficiency of innovative activity of enterprises.] Kharkiv. state. Univ. of Food and Trade, 210 p. [in Ukrainian].

9. Lutsykiv, I. (2010). Ekonomichna sut innovatsiinoi diialnosti.[ The Economic Essence of Innovation.] Galician Economic Bulletin, 2010, No.2 (27), P.89-95. [in Ukrainian].

10. Utterback, J. M., \& Abernathy, W. J. (1975). A dynamic model of process and product innovation. 1975, 3(6), 639-656.

11. Bigliardi, B., Colacino, P., \& Dormio, A. I. (2011). Innovative characteristics of small and medium enterprises. Journal of technology management \& innovation, 6(2), 83-93.

12. Hsiao, S. W., \& Chou, J. R. (2004). A creativity-based design process for innovative product design. International journal of industrial ergonomics, 34(5), 421-443.

13. O'Sullivan, M. (2000). The innovative enterprise and corporate governance. Cambridge Journal of Economics, 24(4), 393-416.

14. Von Hippel, E. (1976). The dominant role of users in the scientific instrument innovation process. Research policy, 5(3), 212-239.

15. Verworn, B., \& Herstatt, C. (2002). The innovation process: an introduction to process models (No. 12). Working paper.

16. Chukhrai, N. I., Lisovska, L.S. (2015). Upravlinnia innovatsiiamy: [navch. posib.].[Innovation Management: [tutorial. tool.].] Polytechnic Publishing House, 277 p. [in Ukrainian].

17. Metodychni rekomendatsii shchodo provedennia analizu rezultatyvnosti naukovo-tekhnichnoi diialnosti (dlia pervynnykh orhanizatsii) // SKhVALENO Rishenniam Vchenoi rady UkrINTEI Protokol vid 28.12.2010 r. \# 10 [17. Methodical recommendations for carrying out the analysis of the effectiveness of scientific and technical activities (for primary organizations) // APPROVED by the Decision of the Scientific Council of UkrINTEI Minutes of December 10, 2010 \# 10][in Ukrainian].

18. Danylenko, Yu. A. (2018). Kharakterystyky ta klasyfikatsii innovatsii ta innovatsiinoho protsesu [Characteristics and Classifications of Innovation and Innovation Process]. Science and Innovation, Vol. 14, No. 3, P.15-30 [in Ukrainian]. Retrieved from:dspace.nbuv.gov.ua/handle/123456789/134025

19. Lacom, P., Bazzaro, F., \& Sagot, J. C. (2017). Proposal of a Modelling of the Innovation Process in an International Manufacturing Company. Journal of technology management \& innovation, 12(2), 26-33.

20. Chukhrai, N. Patora, R.(2001). Innovatsii i lohistyka tovariv: Monohrafiia [Product Innovation and Logistics: Monograph.] Publishing House of Lviv Polytechnic National University, 264 p.[in Ukrainian].

21. Hareev, T. F.. (2006). Evoliutsyia modelei ynnovatsyonnoho protsessa.[ The evolution of innovation process models.] Tisby Bulletin, No. 2, 2006 [Electronic resource]. [inRussion]. Retrieved from: http://www.tisbi.ru/ science/vestnik/2006/issue2/econom4.html.

22. Du Preez, N. D., \& Louw, L. (2008, July). A framework for managing the innovation process. In PICMET'082008 Portland International Conference on Management of Engineering \& Technology (pp. 546-558). IEEE.

23. Holubieva, T. S. (2006). Metodolohichni pidkhody do otsinky efektyvnosti diialnosti pidpryiemstva . [Methodological approaches to assessing the effectiveness of the business.] Actual problems of the economy, No. 5, P.66-71. [in Ukrainian].

24. Chesbrough H. (2003). Open Innovation. The New Imperative for Creating and Profiting from Technology. Harvard Business Press, 2003. Retrieved from: https://eclass.uoa.gr/modules/document/file.php/ECON197/ Papers \%20Strategy/Chesbrough \%20 $2003 \% 20$ The \%20Era \%20of \%20Open \%20Innovation.pdf (date of beast: 12.03 .2020$)$.

25. Rylach, N. M. (2018). Teoretychni osnovy ta suchasni tendentsii rozvytku vidkrytykh innovatsii.[ Theoretical basis and current trends in development of innovation]. International Trade Union Seria "Economic Science", (12). .[in Ukrainian].

26. Lisovska, L. S., Liutak, O. M., \& Zdoroveha, M. V. (2019). Faktory ta problemy nalahodzhennia spivpratsi z pytan innovatsii v Ukraini.[ Factors and problems of establishing innovation cooperation in Ukraine.] .[in Ukrainian].

27. Sobolieva, T. O., \& Hudyma, O. H. (2016). Transformatsiia marketynhu innovatsii v modeliakh innovatsiinoho protsesu [Transformation of innovation marketing in models of innovation process.] Business Inform, (4), 284-288. .[in Ukrainian]. 
28. Fingar, P. (2012). The Innovation Process (Adapted from the book, Business Innovation in the Cloud: Executing on Innovation with Cloud Computing). Available at: https://www.bptrends.com/publicationfiles/06-05-2012COL-EXT \%20COMPETITION--Innovation \%20Process-Fingar-Final.pdf

\author{
Л. С. Лісовська ${ }^{1}$ О. В. Юринець ${ }^{2}$ Б. О.Шеремета ${ }^{1}$ \\ Національний університет “Львівська політехніка", \\ ${ }^{1}$ кафедра менеджменту організацій, \\ ${ }^{2}$ кафедра зовнішньополітичної та митної діяльності
}

\title{
ЗМІНА ПАРАДИГМИ ІННОВАЦІЙНОГО ПРОЦЕСУ НА ЗАСАДАХ ВЗАЕМОДІї
}

(C) Лісовська Л. С., Юринець О. В., Шеремета Б. О, 2020

Досліджено термінологію теоретичної інноватики та уточнено зміст поняття інноваційного процесу. Автори дослідили зміст поняття інноваційної діяльності та інноваційного процесу у законодавстві України та наукових працях вітчизняних та зарубіжних вчених, виявили значні суперечності між ними та невідповідність сучасним реаліям. На підставі аналізування і виконаних досліджень автори запропонували власне вузьке та розширене трактування інноваційного процесу на засадах пріоритетності складової взаємодії.

Інноваційні процеси можна здійснювати за різними моделями, яких у сучасній теорії інноватики нараховують сім: лінійна (технологічного поштовху), лінійна (ринкового витягування), лінійна із зворотними зв'язками взаємодії, інтегрована, мережева; модель відкритих інновацій; модель розширених інноваційних мереж. Автори дослідили еволюцію цих моделей, виділили ключові характеристики їх здійснення, переваги та недоліки реалізації.

Авторами зроблено висновок, що підходи до розуміння та вимог до інноваційного процесу змінюються залежно від динаміки факторів ринку, економічного оточення суб'сктів інновацій: змінюються завдання, цілі, коло учасників. Тому ефективність інноваційного процесу визначається показниками налагодження взаємодії між етапами та учасниками інновацій, переважно інформаційною ефективністю процесу, показниками налагодження комунікацій через інноваційну мережу.

Ключові слова: інноваційна діляьність, взаємодія, ваємодія у інноваціях, інноваційний процес, моделі управління інноваційний процесом, етапи. 